\title{
Conditions for oak selection in Poland
}

\author{
J Sabor \\ Academy of Agriculture, Faculty of Forestry, Department of Seed Production, \\ Nursery and Forest Trees Selection, Kraków, al 29 Listopoada 46, Poland
}

\begin{abstract}
Summary - Details of the occurrence and quality of native oaks (Quercus petraea and $Q$ robur) and a program for their selection in Poland are presented. Most investigations are being carried out at the Forestry Faculty of the Academy of Agriculture in Kraców. They include an analysis of the reasons for oak wilt and investigations into the possibilities of selection on the basis of so-called biologically mature stands once genetic variability has been determined
\end{abstract}

\section{Quercus robur / Quercus petraea / selection / quality / oak decline}

Résumé - Conditions de sélection du chêne en Pologne. Cette contribution rassemble les données relatives à la distribution et à la qualité des peuplements des chênes indigènes de Pologne (Quercus petraea et Quercus robur) et présente un programme d'amélioration des 2 espèces. La plupart de ces recherches sont menées par la faculté forestière de l'Académie d'agriculture de Cracovie. Elles concernent l'analyse des causes du flétrissement des chênes (oak wilt), les perspectives de sélection des chênes dans des peuplements "matures au plan biologique" dès lors que l'amplitude de la variabilité génétique a été appréciée.

\section{Quercus robur / Quercus petraea / sélection / qualité / dépérissement du chêne}

\section{OCCURRENCE}

The genus Quercus is represented in Poland by 3 natives species: sessile oak ( $Q$ petraea (Mattuschka) Liebl), pedunculate oak ( $Q$ robur $L$ ) and pubescent oak ( $Q$ pubescens Willd). Among exotic species, the American eastern red oak ( $Q$ rubra $L$ ) is the most important. Only sessile and pedunculate oaks occur in mixed stands. Both these species are absent from mountains; $Q$ robur reaches a maximum of 600-700 $\mathrm{m}$ above sea level, and $Q$ petraea $700-800 \mathrm{~m}$ in the Carpathian foothills. Sessile oak extends aver all of Poland, except the northern east (see fig 1 ).
Pubescent oak is found in a small enclave at Bielinek on the Oder river in western Poland; in practice, it has no importance for selection or breeding (Bialobok, 1955; Rózanski, 1990).

The important centers of occurrence of oaks (fig 1) are: Krotoszynska province of the Great Poland-Pomeranian region (where it makes up $40 \%$ of the forest area), the East-Lubelska upland province of the Mazowsze-Podlasie region (31\%), the sudety foothill foreland province of the Silesian region $(25 \%)$, and the WestLubelska upland province of the central Polish uplands region (28\%) (Zasady, 1980). 


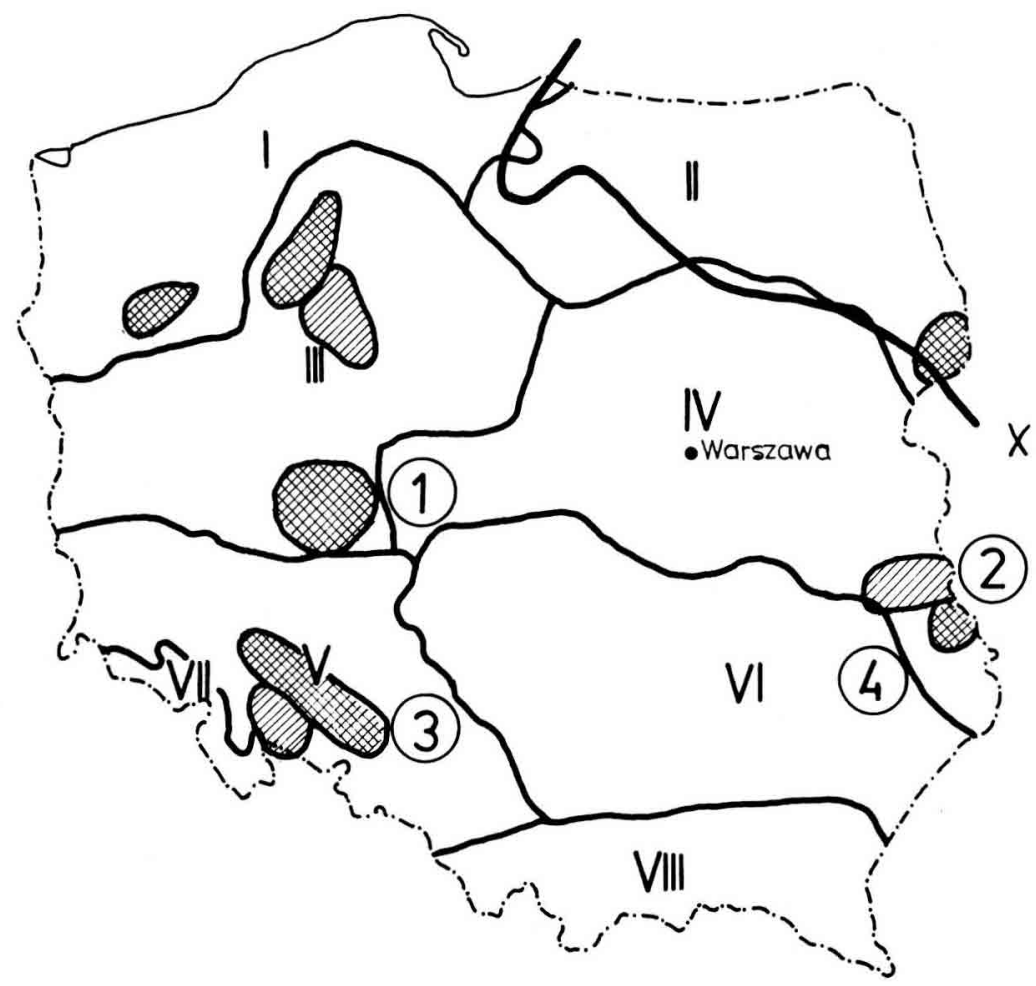

Fig 1. Regions with forest stands of high quality $(\nVdash /)$ ) and the highest quality ( Q petraea Liebl. Locations of stands I-VIII: natural forest regions: I: Baltic region; II: Masuria; III: Great Poland-Pomerania; IV: Mazowsze-Podlasie; V: Silesia; VI: Central Poland uplands; VII: Sudeten Mts; VIII: Carpathian Mt; stands and primeval forests 1-4: 1: Knyszynska Primeval Forest, 2: West-Lubelska upland province, 3: Sudety foothill of Silesian region, 4: East-Lubelska upland of Mazowsze-Podlasie region (Zasady, 1980; Polish provenances).

\section{QUALITY AND OAK WILT}

The stands of highest quality are found in Bialowieza Primaeval Forest in the NE part of Poland; surrounding Barlinek in the Baltic region; in Knyszynska Primeaval Forest in the Great Poland-Pomeranian region and in the southwest between Wroclaw and Opole. In estimating the quality of oak stands, different opinions exist as to the importance of the so-called 'oak wilt' phenomenon which has been recorded many times. In 1942-1943, there was some evidence of decline of over-mature stands in Krotoszynska Primeaval Forest. Signs of oak wilt appeared in 1980 in both pure and mixed stands of ages ranging from 20 to 100 years throughout Poland.

A survey of damage to stands conducted by the Forestry Research Institute, indicated 3 zones of susceptibility. Oak woods in the southern and southwestern regions were most damaged but little damage was recorded among those in the north and north east.

The occurrence of an oak damage grandient in Poland is associated with a disease complex in which drought, low tem- 
peratures, poor soil conditions, air pollution, fungal infections and insect attack all play a part (Rykowski et al, 1990). There has been no genetic interpretation of the phenomenon.

\section{SELECTION PROGRAM}

Oaks are selected according to principles which are generally accepted and practiced with other species. It is based on the choice of seed stands, taking native character of origin, age, quality and productivity into account. Seed orchards and plantations have been established from seed and by vegetative propagation. In 1991 there were 1776 ha of pedunculate oak seed stands $(13.3 \%$ of all seed stands in Poland), 91 ha of sessile oak and 9 ha of red oak seed stands. The breeding value of the progeny of the selected trees is being tested in 609 ha of trials.

This seed resource has been pooriy used so far. Between 1988 and 1990, the total quantity of acorns harvested amounted to 3263 tonnes of which only 104 tonnes $(3.2 \%)$ came from selected stands. Individual tree selection has been developed to a small extent (Kociecki, 1988; Fonder, 1992).

\section{CURRENT INVESTIGATIONS}

Current studies at the Faculty of Forestry in Kraców, in collaboration with the Forestry Research Institute of Warsaw, aim mainly at explaining, analyzing and understanding oak wilt in different regions. The investigations primarily consider pedological, entomological and phytopathological aspects of the problem (Rykowski et al, 1990). Wilt occurs on different soil types but common features of affected sites are an inadequate supply of soil water and air pollution. Investigations have demonstrat- ed the substantial role of herbivorous insects from species in the Geometridae and cambio-xylophagous families.

In phytopathological studies of sick and declining stands, 220 species of fungi have been isolated and 75 identified, among them 2 new species. No significant connection between the genus Ceratocystis and oak wilt has been found.

Dendrochronological analyses have confirmed the relationship between ring width and climatic conditions in influencing the health of oaks (Bednarz, 1987), and botanical studies (Róžański, 1991), describing oak habitat requirements on the basis of different methods of phytosociological analyses of photographs, have proven to be a useful supplement.

Biologically mature stands, as well as selected seed stands, are believed to be the natural basis for population selection (Balut et al, 1985). Biologically mature stands are those which have achieved maturity and yield seed (at $40-50$ years) and in which oaks make up no less than $60 \%$ of the species in the stand, ensuring suitable conditions for pollination. On the basis of these features and the analysis of their quality class and habitat type, a broad base for the subsequent stages of the selection process has been achieved. In the case of oaks, preliminary analyses have shown that, by selecting biologically mature stands, it is possible to obtain a genetic gain. A large variability of quality classes occurs among stands in homogenous habitats (fig 2). Oaks are plastic species in all natural forest regions. For example, in the Silesian region habitat, variability is described by 9 habitat types (ranging from fresh mixed coniferous forest to mixed upland forest).

The present level of selection is at an early stage. However, we hope to make progress through cooperation with other research institutes, including foreign ones. 

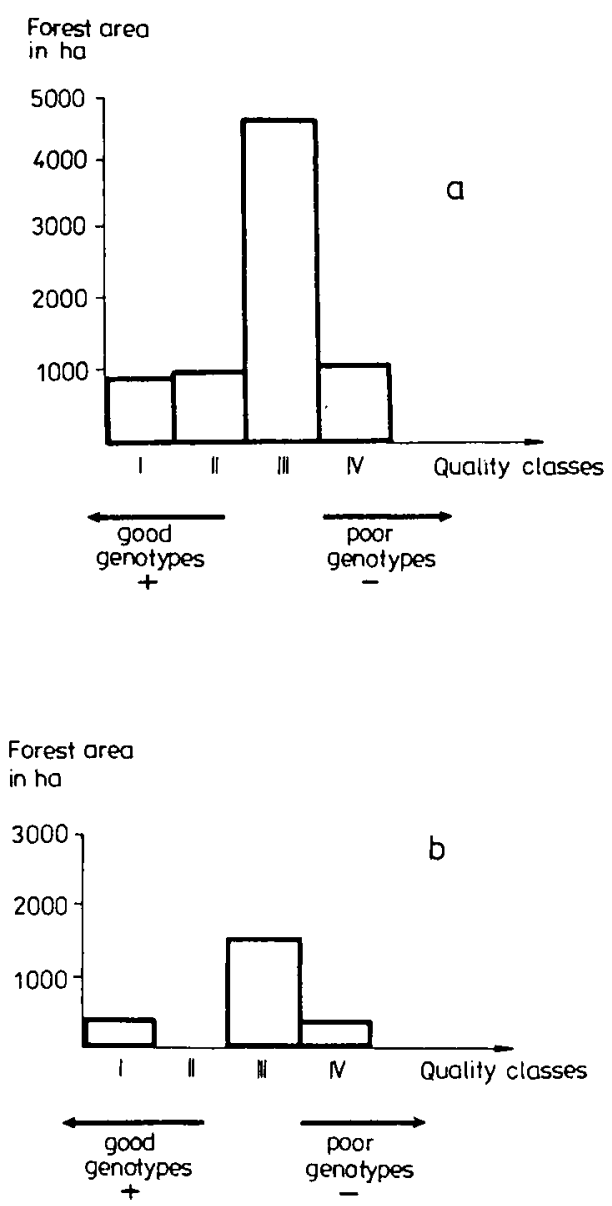

Fig 2. Variability of quality classes of biologically mature oak stands in habitats of mixed forest (a) and mixed coniferous forest (b) in Silesian region $\mathrm{V}$.

\section{REFERENCES}

Balut S, Kulej M, Sabor J, Sobolewska K (1987) Aktualny stan bazy reprodukcyjnej buka zwyczajnego (Fagus silvatica L) w górskich drzewostanach naszego kraju. Sylwan 1987, 35-47

Bednarz Z (1987) The 225-year tree-chronology of the oak (Quercus robur $L$ ) in the Niepolomice Forest near Kraków. Dendrochronologia 5, 59-68

Bialobok S (1955) Drzewoznastwo. Warszawa PWRiL, 194-204

Fonder W (1992) Plantacje nasienne w lasach panstwowych. In: Program zachowania les' nych zasobów genowych i hodowli selekcyjnej drzew Leśnych w Polsce na lata 19912010. Monograph edited by Forestry Research Institute, 23-58

Kociecki S (1988) Wytyszne w sprawie seleckcji drzew na potrzeby naisiennictwa leśnego. $\mathrm{Pr}$ Inst Badow Lesn Ser B nr 7 Warszana edited by IBL, Warszawa

Polish Proveniences of Seed and Seedlings of Norway Spruce, Scotch pine, Polish larch, Sudeten variety of European larch, pedunculate oak and beach. Editor PAGET, Warszawa

Rózanski W (1991) Conditions for the occurrence and site requirements of some important forest tree species in the Pogórze Wielickie foothill and adjacent part of Beskidy Mountains on the phytosociological data. Zesz Nauk AR Kraków Z Lesn 20, 181-202

Rykowski K, Domanski S, Strazyk J, Maciaszek W, Olszako W (1990) Zmiany odpornosci biologicznej drzewostanów lisciastych (Dab buk jesion) przyczyny, przebieg, zamieranie i zwiazek ze zmianami srodowiska. Scientific report NCR 444, Warszawa-Kraków

Zasady HL (1980) Kryteria rozpoznania przyrodniczych warunków produkcji lesnej. PWRiL, Warszawa 